\title{
Defenses of Caribbean sponges against predatory reef fish. II. Spicules, tissue toughness, and nutritional quality
}

\author{
Brian Chanas, Joseph R. Pawlik* \\ Biological Sciences and Center for Marine Science Research, University of North Carolina at Wilmington, \\ Wilmington, North Carolina 28403-3297, USA
}

\begin{abstract}
Laboratory and field feeding experiments were conducted to assess the palatability to predatory reef fish of prepared foods containing natural concentrations of glass spicules from 8 species of Caribbean reef sponges. Sponge species with high concentrations of spicules in their tissues, and with variable spicule morphologies, were chosen for the experiments. The presence of spicules did not alter food palatability relative to controls for any of the sponges tested. Analyses of ash content, tensile strength, protein, carbohydrate, and lipid content, and total energy content were conducted on tissue samples from 71 species of Caribbean demosponges from reef, mangrove, and grassbed habitats, and compared to previously reported data on the chemical defenses of the same species. There was no evidence to support the hypothesis that sponge species with palatable extracts have higher concentrations of inorganic structural elements, as measured by the mean ash content of their tissues. In addition, the tissues of palatable sponges were not different from those of chemically deterrent species with regard to mean tensile strength, protein content, carbohydrate content, and total energy content, but the tissues of chemically defended species did have a higher mean lipid content than those of palatable species. Sponges that lack chemical antipredatory defenses do not appear to compensate with structural or nutritional defenses, but may instead direct energy otherwise used for the production and storage of secondary metabolites to increased growth and reproduction.
\end{abstract}

KEY WORDS: Sponge - Defense - Caribbean - Coral reef Predation - Spicules - Nutritional value Toughness

\section{INTRODUCTION}

Tropical reef ecosystems are characterized by high levels of herbivory and predation (Huston 1985, Hay 1991), yet these environments are dominated by fleshy, sessile, benthic invertebrates and plants. The defensive options available to marine organisms can include one or several of the following: (1) chemical defenses (demonstrated for several sponges, corals, tunicates, etc.); (2) structural defenses, including shells (most gastropods), spines, pincers (many echinoderms, bryozoans), or skeletal elements such as an endoskeleton (hard corals), sclerites (soft corals), or spicules (sponges); (3) tissue

'Addressee for correspondence.

E-mail: pawlikj@vxc.uncwil.edu toughness (as in some holothurians) that may exceed the abilities of most predators to bite or tear prey; and (4) reduced tissue food value that renders prey largely undigestible, including the perfusion of tissue with water (many cnidarians), calcium carbonate (red and green algae), cellulose (tunicates) or refractory collagen (sponges). In the preceding contribution (Pawlik et al. 1995, this issue), we investigated the first of these strategies, chemical defense, as elaborated by 71 species of Caribbean demosponges. We discovered that $69 \%$ of these species yielded organic extracts that deterred the feeding of a predatory reef fish, but many very common sponges produced palatable extracts. In this paper, we survey the same species of sponges with regard to the other 3 defensive strategies: structural elements, tissue toughness, and nutritional quality. 
Structural defenses of terrestrial and marine plants ('quantitative' defenses as defined by Feeny 1976) have been the subject of noteworthy research; these defenses include resins and lignins of terrestrial plants (Rosenthal \& Janzen 1979, Coley 1983) and calcified inclusions of marine algae (Littler et al. 1983, Paul 1992, Hay et al. 1994). For sessile marine invertebrates, spicules and sclerites are known to play an important role in colony support (Koehl 1982, Lewis \& VonWallis 1991), but their defensive function has been debated. For example, Harvell et al. (1988) demonstrated that the addition of sclerites from the coenenchyme tissues of the gorgonian Pseudopterogorgia acerosa to food strips reduced their consumption by reef fish in field assays, but Wylie \& Paul (1989) reported that butterflyfish preferred to feed on species of the soft coral SinuJaria that had the greatest concentrations of large, sharp sclerites.

Demosponges show considerable diversity of structural elements; most have siliceous spicules (which can vary considerably in size and shape, depending on the species) and proteinaceous spongin fibers (which are similarly variable), but many have only the latter (e.g. Verongida, Dictyoceratida) and some have neither (e.g. some Homosclerophorida) (Bergquist 1978). Spicules may offer an effective structural defense against generalist predators, as they do for some gorgonian corals (Harvell et al. 1988, VanAlstyne \& Paul 1992), but it appears that they are not effective against some sponge specialists (Randall \& Hartman 1968, Meylan 1988). Proteinaceous spongin fibers may be indigestible for some generalist predators, and if the fraction of indigestible material (spicules + spongin) is too high, predators may not eat the sponge tissue, as has been found for some herbivores feeding on woody plants (Mattson et al. 1988) and calcified seaweeds (Paul \& VanAlstyne 1988, Hay et al. 1994). Recent studies of the interaction of chemical defenses and food nutritional quality by Duffy \& Paul (1992) and Pennings et al. (1994) revealed that prepared foods having a high protein content and also containing algal or sponge metabolites were readily eaten by reef predators, but low protein foods containing the same compounds deterred predation. Therefore, if the nutritional value of tissue is sufficiently low, it may offer a selective advantage to an organism (1) by decreasing tissue palatability, (2) by increasing the effectiveness of chemical defenses, and, if the nutritional value is decreased through the addition of structural elements, (3) by increasing tissue toughness and resilience to physical harm. It stands to reason that any defensive mechanism will have a metabolic cost, so that the greater elaboration of any combination of chemical and structural defenses will be counterbalanced by reductions in growth and fecundity.
Considering the foregoing, one could make the following predictions when examining the relationships between structural elements, tissue toughness, food value, and chemical defenses in a suite of Caribbean demosponges: species with highly deterrent crude organic extracts (potent chemical defenses) are more likely to have tissues (1) with fewer inorganic structural elements, (2) that are less tough, and (3) with higher food value, than species with palatable crude organic extracts. To address these hypotheses, we assembled data on spicule content (as ash mass), tissue toughness (as tensile strength), and nutritional quality (as protein, carbohydrate, lipid, and energy content) for 71 species of Caribbean demosponges and compared these to the data on the chemical defenses of the same species (Pawlik et al. 1995). In addition, we tested the capacity of the siliceous spicules of 8 species to deter predation by offering prepared foods containing natural concentrations of spicules to predatory reef fish in aquarium and field assays.

\section{MATERIALS AND METHODS}

Sponge collection and identification. This study was conducted over the course of 5 research expeditions: 2 on board the RV 'Columbus Iselin' to the Bahamas Islands in July 1992 and August 1993, 1 on board the RV 'Seward Johnson' in October 1994, and 2 at the National Undersea Research Program facility in Key Largo, Florida, USA, in December 1992 and again in May 1994. Portions of sponges were collected by gently tearing, or when necessary, by cutting tissue with a sharp knife. Sponges were collected from reef, mangrove, and seagrass bed habitats. For each species, replicate collections were taken from distant sites to avoid collecting asexually produced clones. Tissue was immediately frozen and stored at $20^{\circ} \mathrm{C}$ until used in subsequent biochemical and tensile strength analyses. Sponges were identified on the basis of spicule and tissue preparations (DeLaubenfels 1936, Wiedenmayer 1977, Zea 1987, Kelly-Borges \& Pomponi 1992, R. W. M. VanSoest unpubl.).

Laboratory assays. Aquarium assays were performed as described in Pawlik et al. (1995) on board the RV 'Columbus Iselin' using tissue from 5 species of highly spiculose sponges, representing a range of spicule types. The species assayed were: Cribrochalina vasculum, Geodia neptuni, Mycale laevis, Neofibularia nolitangere, and Xestospongia muta. A duplicate assay was performed on different specimens of the last 3 species, collected from different sites. A $10 \mathrm{ml}$ volume of sponge ectosome tissue (within $1 \mathrm{~cm}$ of sponge surface) was measured by displacement 
into a graduated $50 \mathrm{ml}$ plastic centrifuge tube filled with $40 \mathrm{ml}$ of water. The water was discarded and the tube filled with chlorine bleach (sodium hypochlorite, $5.25 \%$ ). After the solution stopped bubbling ( 1 to $5 \mathrm{~h}$ ), the supernatant was carefully decanted, and fresh bleach added. This process was repeated until the addition of fresh bleach resulted in no further bubbling (usually 3 treatments), and a pellet of spicules was left on the bottom of the tube. After the final treatment, the bleach was decanted and replaced with distilled water. The distilled water was decanted and replaced for a total of 3 rinses. After the last rinse, the water was replaced with a $1.0 \mathrm{M}$ solution of sodium thiosulfate to neutralize any residual bleach. After 10 to $15 \mathrm{~min}$, the spicule pellet was rinsed 3 times in distilled water, and then transferred to a glass scintillation vial.

A mixture of $0.3 \mathrm{~g}$ alginic acid and $0.5 \mathrm{~g}$ of freezedried, powdered squid mantle in distilled water was added to each vial containing the spicule pellet from $10 \mathrm{ml}$ of sponge tissue to yield a final volume of $10 \mathrm{ml}$. The mixture was gently stirred to homogenously distribute the spicules in the alginic acid matrix while avoiding breakage of spicules. The mixture was then loaded into a $10 \mathrm{ml}$ syringe, the syringe tip was submerged in a $0.25 \mathrm{M}$ solution of calcium chloride, and the contents of the syringe emptied to form a long, spaghetti-like strand. After a few minutes, the hardened strand was removed, rinsed in seawater, and chopped into $4 \mathrm{~mm}$ long pellets with a razor blade. Control pellets were made the same way, but without addition of spicules. Control and treated pellets were presented to groups of 3 bluehead wrasses Thalassoma bifasciatum ( 1 blue-head phase, 2 yellow phase) held in each of 10 separate, opaque-sided compartments in laboratory aquaria, as described in Pawlik et al. (1995). Excess pellets not used in feeding assays were treated with bleach as before to yield spicules that were then examined for breakage.

Field assays. Experiments were performed as described in Pawlik \& Fenical (1992) on shallow $(<10 \mathrm{~m})$ reefs in the Bahamas. A spicule pellet from $60 \mathrm{ml}$ of sponge tissue was prepared as before (see 'Laboratory assays') from samples of Agelas clathrodes, Chondrilla nucula, Ectyoplasia ferox, Neofibularia nolitangere and Xestospongia muta. For each species, the spicule pellet was gently homogenized into a pre-mixed matrix of $1.5 \mathrm{~g}$ of carrageenan (Type I, Sigma) and $3.0 \mathrm{~g}$ of freeze-dried, powdered squid mantle, and brought to a final volume of $65 \mathrm{ml}$ with distilled water. The mixture was heated to boiling in a microwave oven (about 1 min on full power), then poured into plastic molds crossed by lengths of cotton string that protruded from the ends of the molds. After the matrix cooled, the total volume of the gel was $60 \mathrm{ml}$; approximately $5 \mathrm{ml}$ of volume was lost as water vapor. The gel was sliced into $1.0 \times 0.5 \times$ $0.5 \mathrm{~cm}$ strips with a scalpel, each strip having a string embedded in its center For each experiment, 20 spicule treated and 20 control strips were prepared. To distinguish treated from control strips, the cotton string attached to each strip was marked with a small colored ink spot.

Field assays were based on those of Hay (1984). One treated and one control strip each were tied to a $50 \mathrm{~cm}$ length of 3-strand nylon rope at a distance of $\sim 4$ and $12 \mathrm{~cm}$ from one end of the rope (the order was haphazard). Twenty ropes were deployed on the reef for each experiment, with the end of each rope opposite the food strips unwound and clamped onto a piece of coral or rock. Identifications of fish sampling food strips were made by consulting Randall (1983) and Humann (1989). Within $1 \mathrm{~h}$, the ropes were retrieved and the percentage decrease in the strip length recorded to the nearest $5 \%$. The Wilcoxon paired-sample test (1tailed; Zar 1984) was employed to analyze the results after excluding pairs for which both control and treated strips had been either completely eaten, or not eaten at all.

Measuring ash mass. Frozen tissue samples from each of 3 or more individuals from each of 71 species of Caribbean sponges were weighed (wet mass) and their volume determined by displacement of distilled water. Samples were freeze-dried for $12 \mathrm{~h}$, weighed (dry mass), and extracted twice: first in 1:1 dichloromethane:methanol for $24 \mathrm{~h}$, then in methanol for $1 \mathrm{~h}$. The 2 extracts were combined, evaporated on a warming tray at $60^{\circ} \mathrm{C}$ and weighed (extract mass). The extract and extracted tissue were recombined and ashed at $450^{\circ} \mathrm{C}$ in a muffle furnace for $12 \mathrm{~h}$, then weighed (ash mass). This combustion temperature has commonly been used to ash organic material but retain water that is bound in mineralized skeletons (Paine 1964, Harvell \& Fenical 1989, Bjorndal 1990), Ash content was compared with data on the deterrency of crude organic extracts from the same sponge species (Pawlik et al. 1995) to determine whether a relationship exists between the content of inorganic structural elements and chemical defense Further, the ash mass data were divided into 2 groups, data from sponges with palatable crude extracts, and data from sponges with deterrent crude extracts (Pawlik et al. 1995), and significant differences in the means of the 2 groups determined with a $t$-test (Zar 1984).

Measuring tensile strength. Frozen tissue samples of each of 3 individuals from each sponge species were allowed to thaw to $\sim 25^{\circ} \mathrm{C}$. For each sample, 3 thin, rectangular strips of tissue were cut and the crosssectional area estimated by measuring the width and 
thickness to the nearest $1.0 \mathrm{~mm}$. Each strip was gripped lengthwise at both ends with spring-steel paper clamps equipped with thin corrugated aluminium strips to prevent tissue slippage. The clamp at one end of the strip was attached to a support, while a tripour beaker was suspended from the clamp at the other end of the strip. Distilled water was slowly added to the beaker until the tissue failed along the measured cross-sectional area between the clamps. Trials in which failure occurred at the clamp edge, or obliquely to the cross-sectional area, were not recorded. Tensile strength was calculated as follows:

$$
\sigma_{n}=F \times A^{-1}
$$

where $\sigma_{n}$ is the nominal stress at failure $\left(\mathrm{N} \mathrm{m}^{-2}\right), A$ is the cross-sectional area $\left(\mathrm{m}^{2}\right)$, and

$$
F=m \times g
$$

where $F$ is the force $(N), m$ is the combined mass of the water, beaker, and clamp $(\mathrm{kg})$, and $g$ is gravitational acceleration, $9.8 \mathrm{~m} \mathrm{~s}^{-2}$

The mean tensile strength of 3 tissue strips was computed for each sample, and a mean of the 3 replicate sample means was taken for each sponge species. Some species had tissue that was too weak to test using this method, while others were too strong (the clamps would slip before the tissue would fail). For 19 species, the tensile strength of freshly collected tissue samples was measured using the same techniques, and these values were comparable to those of thawed tissue from the same species; therefore, only the data from analyses of thawed tissue are reported herein. Tensile strength was compared with data on the deterrency of crude organic extracts from the same sponge species (Pawlik et al. 1995) to determine whether a relationship exists between tensile strength and chemical defense. Further, tensile strength data were divided into 2 groups, those from sponges with palatable crude extracts, and those from sponges with deterrent crude extracts (Pawlik et al. 1995), and significant differences in the means of the 2 groups determined with a t-test (Zar 1984).

Measuring nutritional quality. The techniques of McClintock (1987) were adapted to measure the nutritional value of sponge tissue. Frozen tissue samples of at least 3 individuals from each sponge species were separately freeze-dried and ground to a fine powder in a high-speed mill (CRC micro-mill). Subsamples of powder were weighed and subjected to the following analyses based on well-established protocols: (1) $\mathrm{NaOH}$-soluble protein content (Bradford 1976) using bovine serum albumen as a standard, (2) TCA-soluble carbohydrate content (Dubois et al. 1956) using glycogen as a standard, (3) lipid content using a gravimetric technique (Freeman et al. 1957), and (4) total energy content by combustion in a Parr oxygen bomb calorimeter (as in Dayton et al. 1974). Samples of assay foods were subjected to the same analyses. Because potential predators consume tissue on the basis of volume, rather than mass, all values for protein, carbohydrate, and lipid (as $\mathrm{mg}$ ) and energy content (as kJ) were expressed on a per volume basis calculated from the ratio of mean dry mass:volume for each sponge species (see 'Measuring ash mass'). This standardization is particularly important because sponges vary widely in their density, because of differences both in spicule mass and in the amount of water present in the tissues. All 4 values relating to nutritional quality were compared with data on the deterrency of crude organic extracts from the same sponge species (Pawlik et al. 1995) to determine whether relationships exist between these nutritional values and chemical defense. Further, data on nutritional quality were each divided into 2 groups, data from sponges with palatable crude extracts, and data from sponges with deterrent crude extracts (Pawlik et al. 1995), and significant differences in the means of the 2 groups determined with a $t$-test (Zar 1984).

\section{RESULTS}

\section{Deterrency of spicules}

Five species of reef sponges were chosen for aquarium assays of their spicules at concentrations that occur naturally in sponge surface tissues (Fig 1). All 5 species have a high density of spicules in their tissues, with a range of spicule sizes and morphologies (see Figs. 1 \& 2). Thalassoma bifasciatum readily ate spicule-laden food pellets in every case (Fig. 1). Fish swallowed spicule-treated pellets without any immediate or long term ill effects (i.e. no flaring of gills or regurgitation, as seen with food pellets treated with mildly unpalatable organic extracts, and no negative effects after several weeks of subsequent captivity). Spicules were reclaimed from unused food pellets by treating them with bleach (see 'Materials and methods') and compared with spicules that had not been incorporated into food, and there were no obvious increases in the amount of spicule breakage due to food preparation.

Field assays of the spicules of 5 sponge species at natural concentrations also revealed no inhibition of feeding by a natural assemblage of reef fish (Fig 2). There was a significant difference in feeding on food strips perfused with the spicules of Chondrilla nucula (Fig. 2B), but more bites had been taken of treated food strips than controls (Wilcoxon signed rank test, $p=0.04,1$-tailed test). A wide variety of fish fed on 
Fig. 1 Aquarium assay. Consumption by Thalassoma bifasciatum of food pellets (mean $+\mathrm{SE}$ ) containing sponge spicules at natural concentrations Fish consumed all 10 control pellets in all cases. The number of replicate assays follows each species name. Drawings of representative spicule types are indicated for the first 3 species (adapted from Zea 1987), while spicules of the last 2 species are shown in Fig. 2. All the spicules are drawn to the same scale (bar on right), except for the 2 in the left-most part of the figure from Geodia neptuni

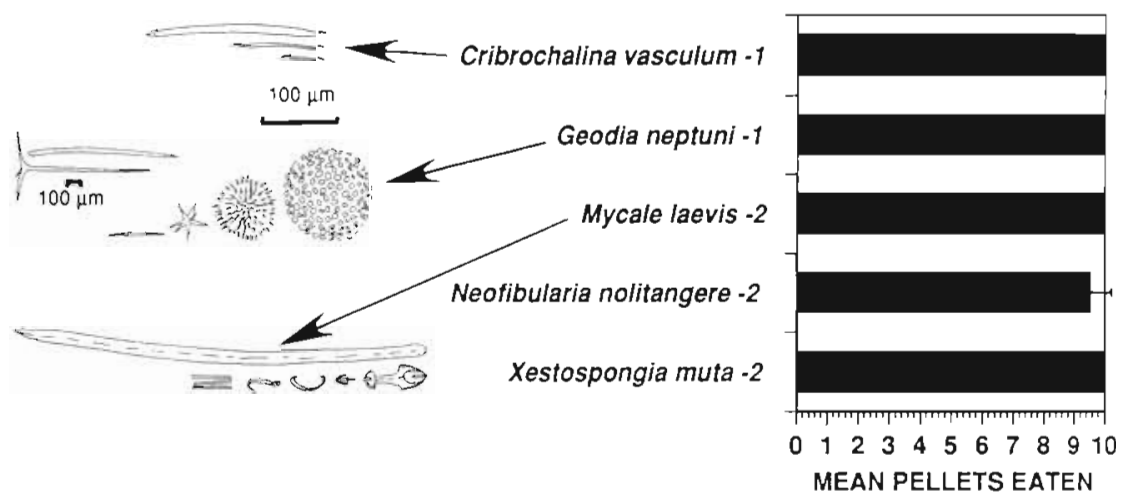

treated and control food strips, particularly wrasses Thalassoma and Halichoeres spp., snappers Ocyurus chrysurus, parrotfish Scarus and Sparisoma spp., grunts Haemulon spp., tilefish Malancanthus plumieri, porgy Calamus spp. and angelfish Pomacanthus arcuatus.

\section{Ash mass compared with extract palatability}

The ash mass of tissue was determined for all 71 Caribbean sponge species (Fig. 3). The mean concentration ( $\pm \mathrm{SD}$ ) of ash was $78.4 \pm 84.7 \mathrm{mg} \mathrm{ml}^{-1}$ The composition of the ash varied depending on the sponge: for most species, the ash residue was composed mostly of glass spicules (e.g. Placospongia melobesioides, Geodia neptuni, Xestospongia muta), but in others it was primarily carbonate sand (e.g. Dysidea janiae) or inorganic salts from the seawater held by the tissue of some species (e.g. all Aplysina and Ircinia spp.). The highest ash mass values were among highly spiculose species in the tetractinomorph families Placospongiidae. Spirastellidae, and Geodiidae. For the purposes of comparisons with other studies in which all ash and nutritional values are expressed on the basis of dry mass, mean values of extract mass and dry mass per volume are listed in Table 1
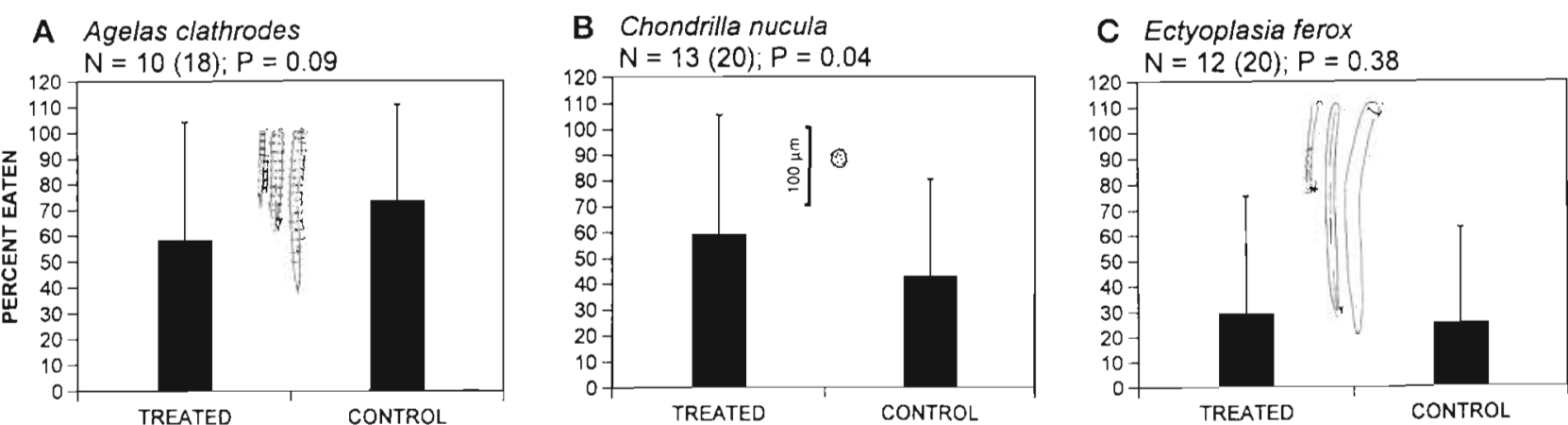

Fig. 2. Field assay. Consumption by reef fishes of paired control food strips and strips containing spicules at the same concentrations as found in sponge tissues. $1 \mathrm{SD}$ above the mean is indicated. $\mathrm{N}=$ no. of paired treated and control strips used in statistical analysis (no. of pairs retrieved of 20 deployed). Probability calculated using the Wilcoxon paired-sample test. Drawings of representative spicule types are indicated for each species (adapted from Zea 1987), and are drawn to the same scale (given in $\mathrm{B}$ )
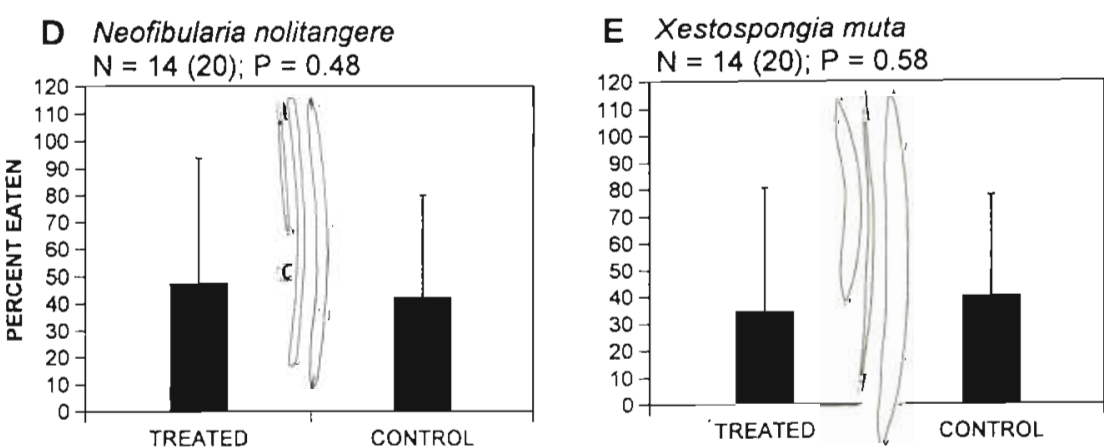





Table 1. Mean extract mass ( $\mathrm{mg} \mathrm{ml}^{-1}$ ) and dry mass $\left(\mathrm{mg} \mathrm{ml}^{-1}\right.$ ) of the tissue of 71 species of Caribbean demosponges

\begin{tabular}{|c|c|c|c|c|c|c|c|}
\hline Species & $\mathrm{n}$ & Extract & Dry mass & Species & $n$ & Extract & Dry mass \\
\hline Agelas clathrodes & 5 & 35 & 153 & Ircinia felix & 3 & 35 & 142 \\
\hline Agelas conifera & 3 & 36 & 180 & Ircinia strobilina & 3 & 29 & 150 \\
\hline Agelas dispar & 3 & 31 & 142 & Lissodendoryx isodictyalis & 3 & 23 & 126 \\
\hline Agelas inequalis & 3 & 39 & 170 & Lissodendoryx sigmata & 2 & 27 & 68 \\
\hline Agelas sceptrum & 3 & 35 & 154 & Mycale laevis & 3 & 23 & 132 \\
\hline Agelas wiedenmayeri & 3 & 38 & 188 & Mycale laxissima & 3 & 23 & 156 \\
\hline Amphimedon compressa & 7 & 37 & 137 & Myrmekioderma styx & 3 & 35 & 166 \\
\hline Amphumedon erina & 3 & 33 & 139 & Neofibularia nolitangere & 5 & 25 & 190 \\
\hline Anthosigmella varians & 3 & 27 & 144 & Niphates digitalis & 3 & 31 & 95 \\
\hline Aplysina archeri & 3 & 45 & 156 & Niphates erecta & 3 & 33 & 126 \\
\hline Aplysina cauliformis & 3 & 44 & 178 & Pandaros acanthifolium & 3 & 34 & 163 \\
\hline Aplysina fistularis & 3 & 40 & 187 & Phorbas amaranthus & 3 & 32 & 120 \\
\hline Aplysina fulva & 3 & 39 & 148 & Placospongia melobesioides & 3 & 26 & 787 \\
\hline Aplysina lacunosa & 3 & 34 & 168 & Plakortis angulospiculatus & 1 & 37 & 118 \\
\hline Biemna tubulata & 1 & 35 & 133 & Plakortis halichondroides & 4 & 43 & 214 \\
\hline Callyspongia fallax & 2 & 20 & 164 & Plakortis lita & 3 & 42 & 140 \\
\hline Callyspongia plicifera & 5 & 21 & 136 & Pseudaxinella lunaecharta & 3 & 26 & 161 \\
\hline Callyspongia vaginalis & 3 & 26 & 107 & Pseudoceratina crassa & 3 & 52 & 256 \\
\hline Calyx podotypa & 3 & 32 & 180 & Ptilocaulis spiculifera & 3 & 50 & 160 \\
\hline Chondrilla nucula & 4 & 30 & 176 & Ptilocaulis walpersi & 3 & 31 & 159 \\
\hline Chondrosia collectrix & 3 & 24 & 155 & Rhaphidophlus juniperinus & 3 & 34 & 178 \\
\hline Chondrosia reniformis & 3 & 17 & 238 & Rhaphidophlus venosus & 2 & 27 & 200 \\
\hline Cinachyra alloclada & 3 & 23 & 186 & Siphonodictyon coralliphagum & 3 & 42 & 133 \\
\hline Cribrochalina vasculum & 3 & 29 & 180 & Smenospongia aurea & 3 & 42 & 171 \\
\hline Diplastrella megastellata & 3 & 40 & 377 & Spirastrella coccinea & 2 & 27 & 256 \\
\hline Dysidea etheria & 3 & 37 & 187 & Spongia obliqua & 3 & 24 & 160 \\
\hline Dysidea janiae & 3 & 29 & 182 & Spheciospongia othella & 3 & 33 & 317 \\
\hline Ectyoplasia ferox & 3 & 36 & 191 & Spheciospongia vesparium & 4 & 29 & 334 \\
\hline Erylus formosus & 3 & 62 & 228 & Tedania ignis & 3 & 20 & 85 \\
\hline Geodia gibberosa & 3 & 22 & 239 & Teichaxinella morchellum & 3 & 44 & 158 \\
\hline Geodia neptuni & 3 & 23 & 330 & Tethya actinia & 3 & 28 & 267 \\
\hline Haliclona hogarthi & 3 & 38 & 143 & Ulosa ruetzleri & 3 & 38 & 204 \\
\hline Halichondria melanodocia & 3 & 38 & 127 & Verongula gigantea & 3 & 40 & 185 \\
\hline Hippospongia lachne & 3 & 34 & 119 & Verongula rigida & 3 & 39 & 135 \\
\hline Holopsamma helwigi & 3 & 25 & 153 & Xestospongia muta & 17 & 32 & 171 \\
\hline Iotrochota birotulata & 3 & 25 & 143 & & & & \\
\hline
\end{tabular}

There was little relationship between ash mass and chemical deterrency of sponge extracts [deterrency data from Pawlik et al. (1995); $\mathrm{r}^{2}=0.092$; Fig. 4A]. Although the siope of the correlation was significantly different from zero ( $p=0.012$ ), the low coefficient of determination $\left(\mathrm{r}^{2}\right)$ indicates that sponges that lack chemically deterrent organic extracts do not necessarily have a higher concentration of structural elements in their tissues. The weakness of the relationship was confirmed by comparing the mean tissue ash mass of sponges that yielded unpalatable vs palatable crude organic extracts (Fig. 5A, $p=0.16$, $t$-test).

\section{Tensile strength compared with extract palatability}

The tensile strength of 58 of 71 species of sponges was measured (Fig. 6), with the remaining species having tissue that was either too strong or too weak for an accurate measurement. Tensile strength varied widely across taxa, with a mean value $( \pm \mathrm{SD})$ of $8.8 \pm 15.0 \mathrm{~N} \mathrm{~m}^{-2} \times 10^{5}$. Sponges with the highest tensile strength included Ircinia strobilina and Mycale laxissima, both of which were too strong to measure, and Chondrosia reniformis, Diplastrella megastellata and Teichaxinella morchellum, which gave some of the highest tensile strength values. Sponges in the genera Ptilocaulis and Agelas also had tough tissue.

There was no relationship between mean tissue tensile strength and palatability of tissue organic extracts for the 58 species for which tensile strength was determined $\left(r^{2}=0.007, p=0.606\right.$, Fig. 4B). Surprisingly, many of the toughest sponges also yielded the most deterrent extracts (Pawlik et al. 1995), including all of the species referred to in the preceeding paragraph, with the exception of Chondrosia reniformis. A direct comparison of the mean tissue tensile strength of sponges with palatable and unpalatable organic extracts also revealed no difference (Fig. $5 B, p=0.62$, $t$-test). 


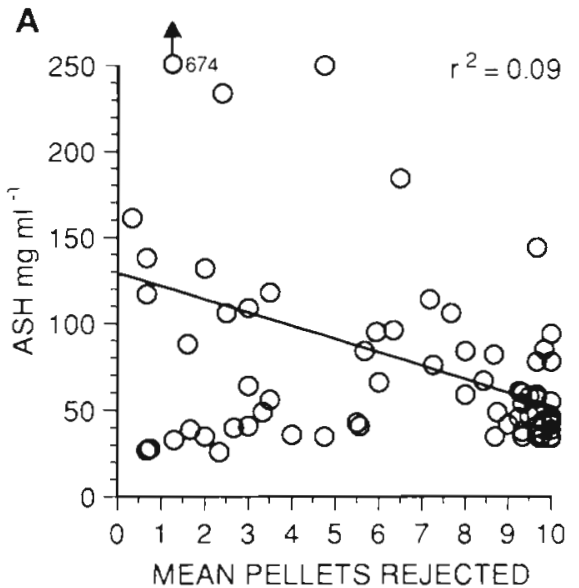

B



Fig. 4. Correlation of the deterrency of organic extracts with (A) ash content $(n=71)$ and (B) tensile strength $(\mathrm{n}=51$ ) of the tissues of Caribbean sponges

\section{Nutritional quality compared with extract palatability}

The nutritional quality expressed as protein content, carbohydrate content, lipid content, and energy content of sponge tissue for 71 species of Caribbean demosponges is shown in Figs. 7 to 10 , respectively. Mean protein, carbohydrate, and lipid contents $( \pm \mathrm{SD}$ ) of sponge tissue were $20.7 \pm 11.6,3.5 \pm 2.2$, and $11.4 \pm$ $8.1 \mathrm{mg} \mathrm{ml}^{-1}$, respectively (Table 2 ). There was little relationship between protein, carbohydrate or lipid contents and the palatability of organic extracts of sponge tissue $\left(\mathrm{r}^{2}=0.006,0.011\right.$, and 0.138 , respectively; Fig. 11A, B, C). The slopes of the correlations were not significant for protein or carbohydrate content ( $p=0.402$ and 0.313 , respectively), but the slope was significant for lipid content $(p<0.001)$. The mean energy content $( \pm \mathrm{SD})$ of sponge tissue was $2.0 \pm$ $0.9 \mathrm{~kJ} \mathrm{ml}^{-1}$, and there was also little relationship between energy content and the deterency of tissue
Table 2. Comparison of nutritional quality of prepared foods used in feeding assays with those of sponge tissue. Values for prepared foods represent means of triplicate analyses, values for sponge tissue are means of means from Figs. 7 to 10 for 71 species

\begin{tabular}{|c|c|c|c|}
\hline $\begin{array}{l}\text { Protein } \\
\left(\mathrm{mg} \mathrm{ml}^{-1}\right)\end{array}$ & $\begin{array}{c}\text { Carbohdrate } \\
\left(\mathrm{mg} \mathrm{ml}^{-1}\right)\end{array}$ & $\begin{array}{c}\text { Lipid } \\
\text { content } \\
\left(\mathrm{mg} \mathrm{m}^{-1}\right)\end{array}$ & $\begin{array}{c}\text { Energy } \\
\left(\mathrm{kJ} \mathrm{ml}^{-1}\right)\end{array}$ \\
\hline \multicolumn{4}{|c|}{ Aquarium assay food pellets } \\
\hline 13.2 & 0.5 & 3.6 & 1.1 \\
\hline \multicolumn{4}{|l|}{ Field assay food strips } \\
\hline 8.9 & 10.6 & 3.1 & 1.1 \\
\hline \multicolumn{4}{|c|}{ Sponge tissue mean $\pm S D, n=71$ ) } \\
\hline $20.7 \pm 11.6$ & $3.5 \pm 2.2$ & $11.4 \pm 8.1$ & $2.0 \pm 0.9$ \\
\hline
\end{tabular}

$\left(r^{2}=0.058 ; p=0.025 ;\right.$ Fig. 11D). When sponges that yielded unpalatable versus palatable crude organic extracts were compared with regard to nutritional quality, there were no differences in mean protein, car-

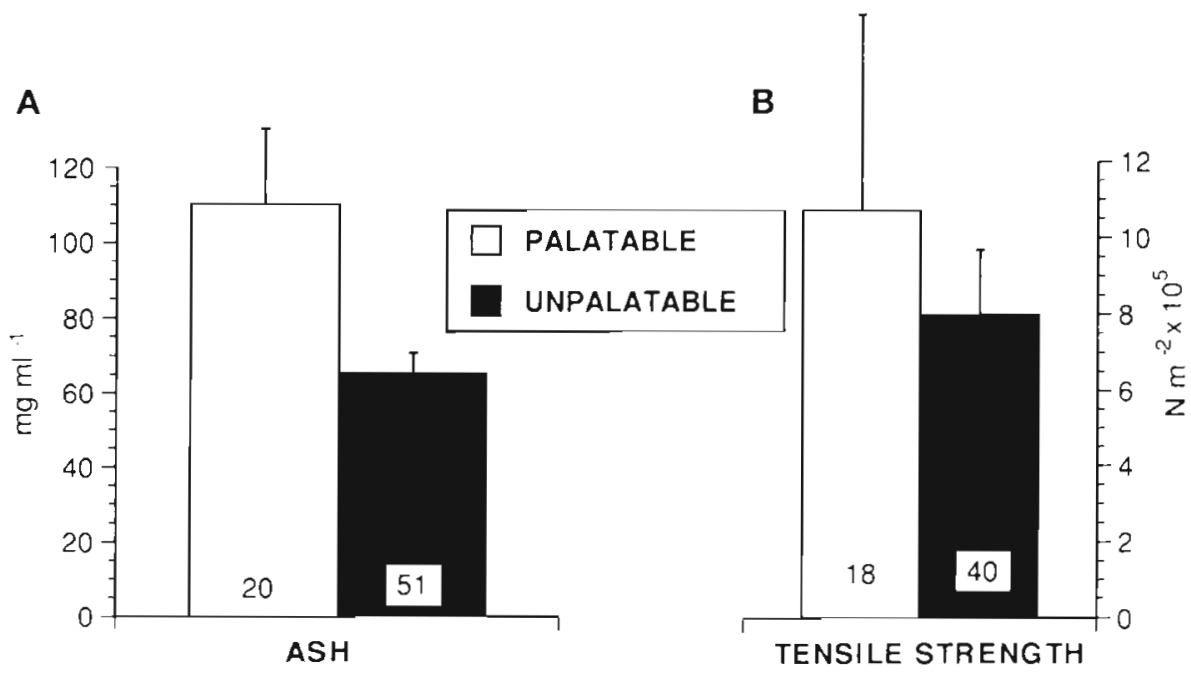

TENSILE STRENGTH
Fig. 5. Comparison of mean (+ SE) ash content (A) and tensile strength $(B)$ of the tissues of sponges that yielded palatable and unpalatable crude organic extracts. The number of species used in each comparison is indicated at the base of each bar. There were no significant differences in the mean values for either comparison $(p>0.05$, t-test) 

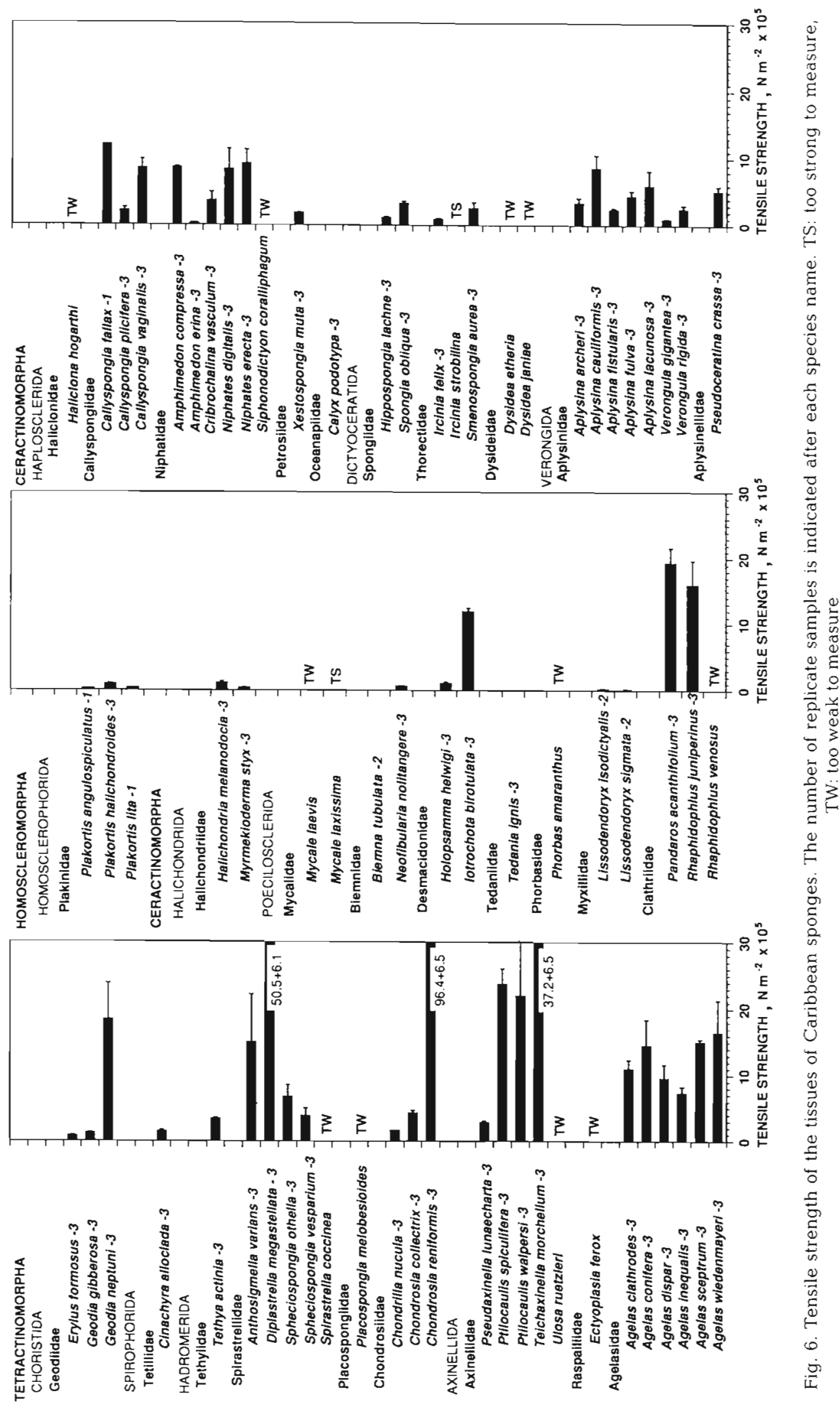

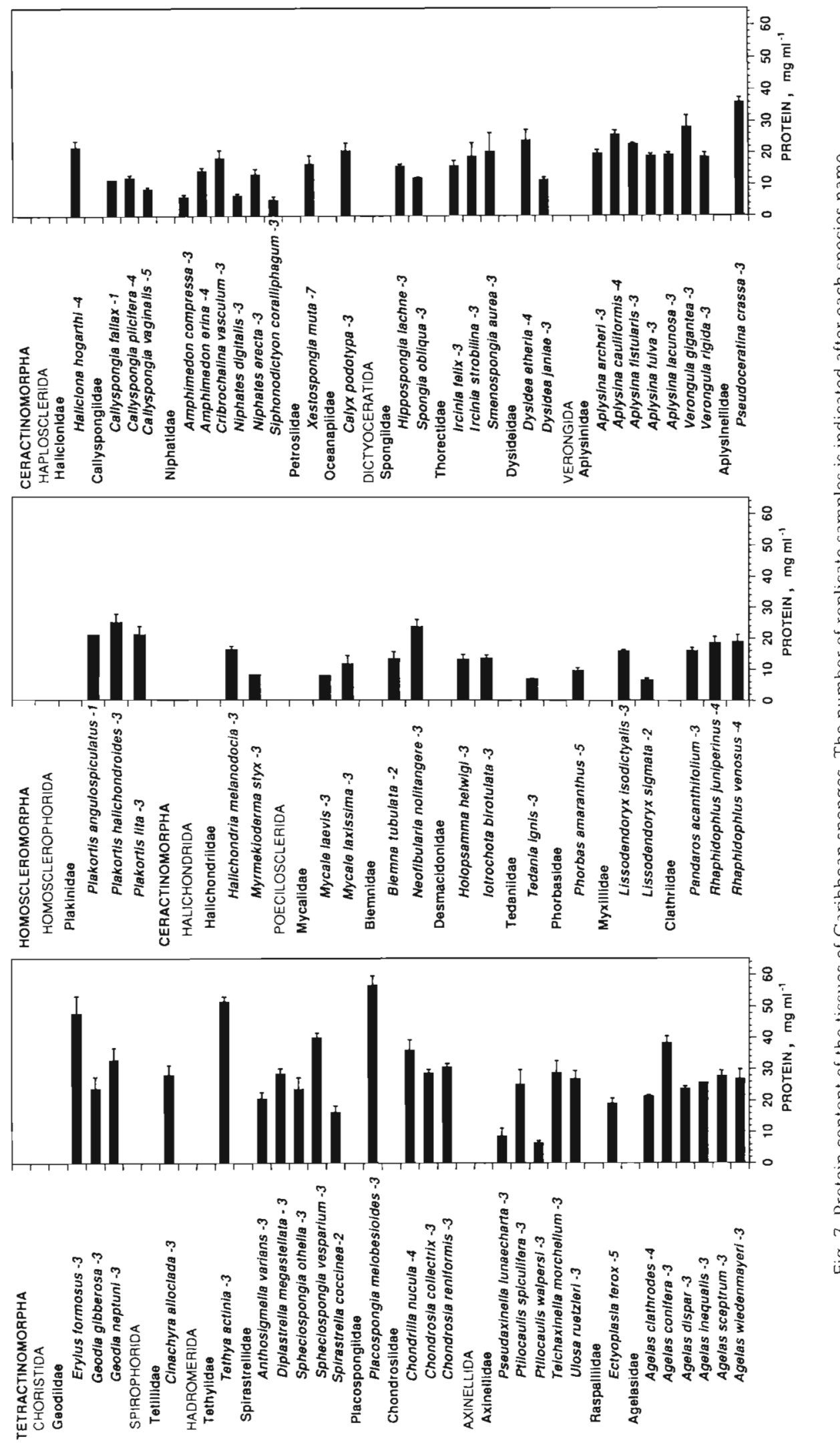

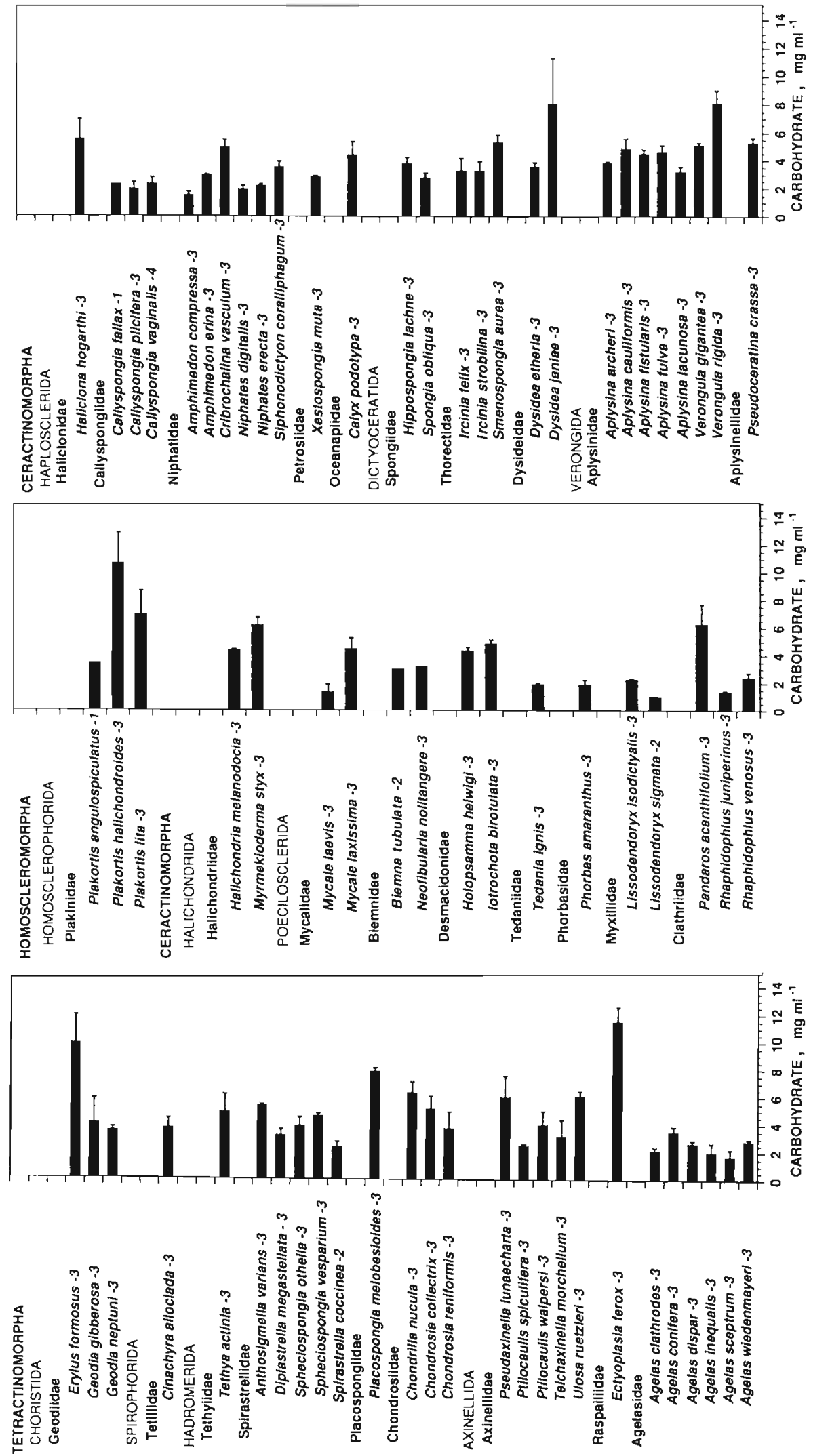



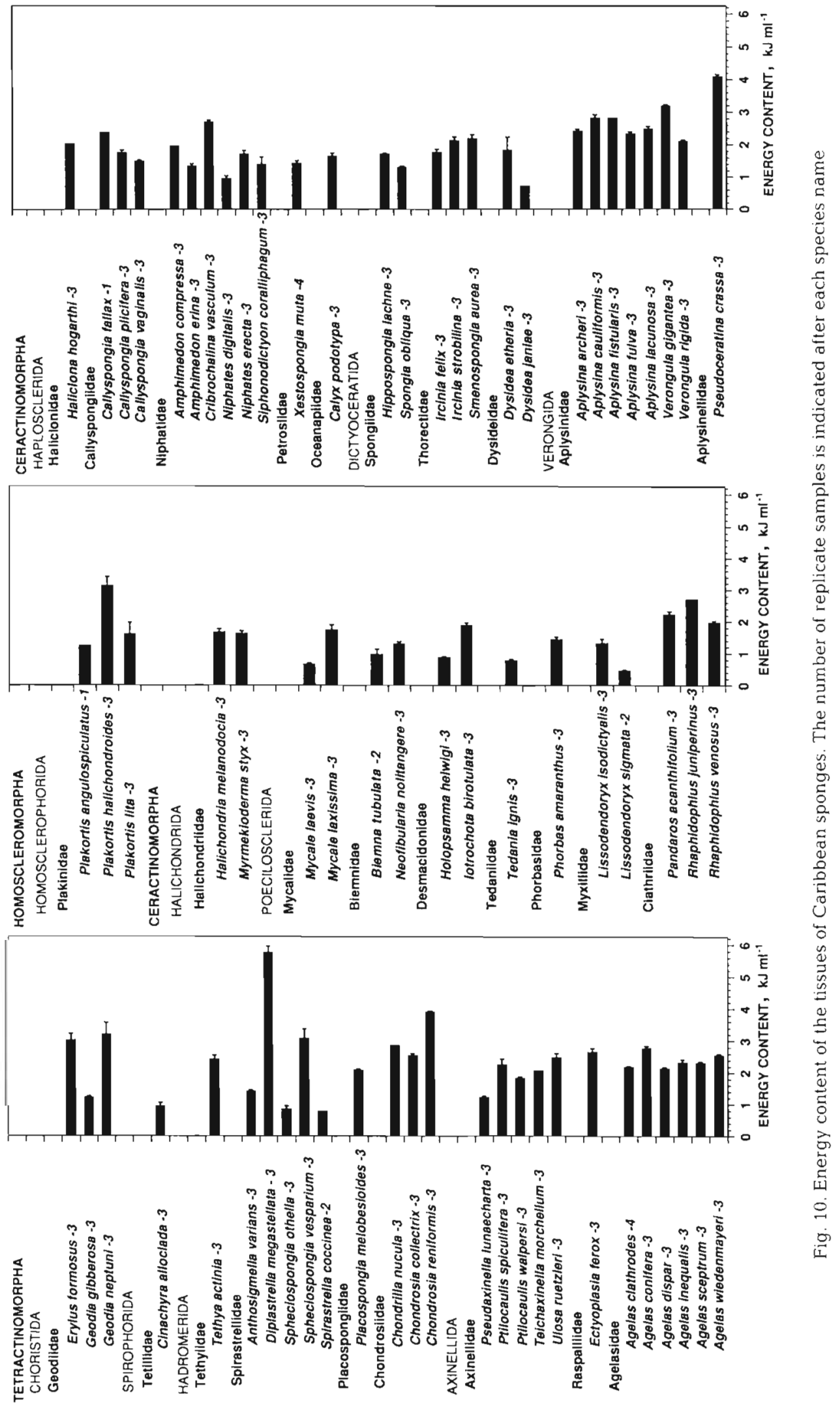
bohydrate, or energy content (Fig. 12A, B, p > 0.05 t-test), but there was a significantly higher lipid content in the tissues of chemically deterrent sponges (Fig. 12A, $p=0.003$, t-test).

\section{DISCUSSION}

\section{Do spicules deter sponge predators?}

Although opaline spicules have long been thought to play a role in defending demosponges from predators (e.g. Hartman 1981), the results of this study suggest that they do not. Prepared foods containing volumetrically equivalent concentrations of spicules did not deter feeding by fish in aquarium or field assays, despite the fact that we chose species that have tissues that are particularly rich in spicules. Some of the species assayed have spicule tracts that run parallel to the sponge surface so that the points are not directed outward (e.g. Neofibularia nolitangere, Xestospongia muta), while others have a perpendicular arrangement (Agelas clathrodes, Ectyoplasia ferox; Zea 1987). The arrangement of spicules in the prepared foods was haphazard, with points directed at all angles, from perpendicular to parallel to the surface. If arrangement was important to the defensive function of spicules, it might be expected that some intermediate level of deterrency would be observed when spicules were improperly arranged in an assay food, but foods perfused with spicules from each species were readily consumed in each case. Moreover, we have subsequently assayed pieces of the skeletons of $A$. clathrodes and $X$. muta in which cellular material was removed by treatment with mild bleach solutions, leaving the spongin and spicule tracts intact, and these were similarly non-deterrent (Chanas 1995). At the same time, spicule morphologydid not appear to have any effect on palatability, because none of the spicule types were deterrent, including oxeas ( $X$. muta), acanthostyles (A. clathrodes), and spherasters (Chondrilla nucula, Geodia neptuni) (Figs. 1 \& 2).

To corroborate the lack of deterrency in field and laboratory assays of sponge spicules, there was no relationship between the concentration of inorganic structural elements and the elaboration of chemical


Fig. 11. Correlation of the deterrency of organic extracts with (A) protein, (B) carbohydrate, (C) lipid and (D) energy content of the tissues of 71 species of Caribbean sponges 
A



B



Fig. 12. Comparison of mean $(+\mathrm{SE})$ protein, carbohydrate and lipid content (A) and energy content (B) of the tissues of sponges that yield palatable and unpalatable crude organic extracts. The mean values of 20 palatable and 51 unpalatable sponges were compared in each case. There were no significant differences in the mean values for any comparison except for lipid content defenses. Ash content was used as a measure of structural elements, whether as siliceous spicules (most species) or incorporated sand grains (e.g. species in the genera Dysidea, Hippospongia, and Spongia). Inverse relationships between the concentrations of structural and chemical defenses have been demonstrated for some marine algae (Hay et al. 1988) and octocorals (e.g. Harvell \& Fenical 1989, see next paragraph), but were not evident in the present study.

Previous investigations have found that calcitic sclerites from the coenenchyme of alcyonacean and gorgonacean corals deter the feeding of both generalist and specialist predators (Gerhart et al. 1988, Harvell et al. 1988, VanAlstyne \& Paul 1992, VanAlstyne et al. 1992, 1994). In light of these past studies, the results of the present investigation are surprising, given that soft coral sclerites are similar in size, morphology, and abundance to the spicules in the tissues of many species of sponges. One important difference may be in the composition of the structural elements: siliceous spicules are largely inert, while sclerites of calcium carbonate may dissolve and alter the $\mathrm{pH}$ of an acidic gut. In this regard, the calcitic sclerites of octocorals may be acting more as an inorganic chemical defense than a structural defense, as has been suggested for calcified algal defenses against herbivores (Hay et al. 1994). Siliceous spicules pass through the guts of sponge-eating marine reptiles (Meylan 1988), fish (Randall \& Hartman 1968), and invertebrates (Birenheide et al. 1993) without obvious long-term ill effects, and the same was noted for the wrasses used as assay fish in the present investigation.

The relationship between the nutritional quality of an assay food and the deterrent capacity of structural elements or secondary metabolites is another important consideration. Recent work by Duffy \& Paul (1992) and Pennings et al. (1994) has demonstrated that low-quality assay foods containing secondary metabolites may be rejected by potential predators, but that high-quality foods containing the same compounds at the same concentrations may be eaten. To address this concern, we analyzed the nutritional quality of control assay foods used in this and the previous study (Pawlik et al. 1995) and compared the values of protein, carbohydrate, lipid, and energy content to the mean values for sponge tissue determined in this study (Table 2). Aquarium assay food used in this study compared favorably with sponge tissue in protein content, which is the nutritional component most likely to influence the effectiveness of a chemical defense (Duffy \& Paul 1992). Therefore, it seems unlikely that the results of feeding experiments in this or the previous study (Pawlik et al. 1995) were influenced by the nutritional quality of the aquarium assay food, but instead by the addition of spicules or organic extracts.

\section{Do chemically undefended sponges have tissues that are tougher or less nutritious?}

The results of this study indicate that there is little difference in tissue toughness and nutritional quality between sponges that have palatable organic tissue extracts and those that have deterrent extracts. The only significant difference was that deterrent sponges had a higher mean concentration of lipid than palatable species (Fig. 12A), but this did not translate into a difference in the mean energy content of the tissues of the 2 groups. Assessments of food quality generally use protein content as a key indicator (Duffy \& Paul 1992, Pennings et al. 1994); in the case of coral reef environments, nitrogen is generally considered to be the limiting nutrient (Grigg et al. 1984), yet there was no difference in the mean protein content of chemically defended and undefended sponges.

It is possible that one major source of protein found in sponges may be unavailable to some generalist con- 
sumers because it requires long periods of digestion. The spongin skeleton of many demosponges, if sufficiently condensed and cross-linked, is difficult to digest (Bjorndal 1990, Meylan 1991). Hawksbill turtles, for example, are unable to fully digest the skeletons of some fibrous sponges (Meylan 1985, 1991). Spongeeating fish, such as angelfish (Randall \& Hartman 1968), may have longer gut retention times, allowing spongin digestion, while other predatory fish, such as wrasses, may eliminate their gut contents before spongin fibers are digested. We have examined the gut contents of several species of angelfish and found that samples from the foregut have clearly identifiable spongin fragments, while hindgut samples do not. This situation may be analogous to that found among terrestrial herbivores that digest cellulose (with the aid of microorganisms) by decreasing the rate of food passage through the gut (as in cows) or by passing food through the gut repeatedly (as in rabbits).

If sponges that are chemically undefended do not use structural or nutritional defenses as an alternative, how do they survive (and thrive, e.g. Callyspongia vaginalis and Niphates erecta) on Caribbean coral reefs? One possibility is that chemically undefended sponges grow faster than unpalatable species, perhaps because energy used for the production of secondary metabolites is instead used for growth. Unlike most other invertebrates, sponges can survive and regenerate after considerable tissue damage, to the point that some reef species appear to rely on storm-induced fragmentation for reproduction (Wulff 1991). Palatable sponges may sustain non-fatal grazing by sponge-eating fish and counter with faster growth. In the same vein, palatable sponges may allocate the energy otherwise used to synthesize secondary metabolites to produce more offspring, and thereby experience higher rates of recruitment to offset the effects of spongivory.

Acknowledgements. Funding for this research was provided by grants from the NOAA/National Undersea Research Program (UNCW9414 to J.R.P.), from the UNCW Graduate School Summer Fellowship Program (to B.C.), and from the National Science Foundation (OCE-9158065 and OCE9314145 to J.R.P); the last of these inciuded support for the use of the research vessels 'Columbus Iselin' and 'Seward Johnson' Although the second author takes full responsibility for any taxonomic errors, we wish to thank Shirley Pomponi, Michelle Kelly-Borges, and Cristina Diaz for their expert help with sponge identifications. Several UNCW undergraduate students provided valuable assistance, particularly Vince Bowman and Victoria Towne. Craig Dahlgren, Rob Toonen, Greg McFall, Alicia Henrikson, David Swearingen, and Matt Dunlap helped with sponge collections. Assistance with biochemical analyses were provided by James McClintock, Thomas Shafer, and David Padgett. Bill Kier provided helpful advice on biomechanics. We thank the captain and crew of the 'Columbus Iselin', the 'Seward Johnson', and the staff of the NOAA/National Undersea Research Center at Key Largo,
Florida, for their cooperation. We are grateful to the government of the Bahamas for permission to perform research in their territorial waters. The authors thank Emmett Duffy and 3 anonymous reviewers for their helpful comments on an earlier version of this paper.

\section{LITERATURE CITED}

Bergquist PR (1978) Sponges. Univ of California Press, Los Angeles

Birenheide $R$, Amemiya $S$, Motokawa $T$ (1993) Penetration and storage of sponge spicules in tissues and coelom of spongivorous echinoids. Mar Biol 115:677-683

Bjorndal K (1990) Digestibility of the sponge Chondrilla nucula in the green turtle, Chelonia mydas. Bull mar Sci 47:567-570

Bradford MM (1976) A rapid and sensitive method for the quatification of microgram quantities of protein utilizing the principle of protein-dye binding. Analyt Biochem 72: $248-254$

Chanas B (1995) Physical and chemical defenses of three Caribbean sponges. MSc dissertation, Univ of North Carolina, Wilmington

Coley PD (1983) Herbivory and defensive characteristics of tree species in a lowland tropical forest. Ecol Monogr 53:209-233

Dayton PK, Robilliard GA, Paine RT, Dayton LB (1974) Biological accommodation in the benthic community at McMurdo Sound, Antarctica. Ecol Monogr 44:105-128

DeLaubenfels MW (1936) A discussion of the sponge fauna of the Dry Tortugas in particular, and the West Indies in general, with material for a revision of the families and orders of the Porifera. Papers Tortugas Lab 30. Carnegie Inst Wash Publ 467

Dubois M, Gilles KA, Hamilton JK, Rebers PA, Smith F (1956) Colorimetric method for determination of sugars and related substances. Analyt Chem 28:350-356

Duffy JE, Paul VJ (1992) Prey nutritional quality and the effectiveness of chemical defenses against tropical reef fishes. Oecologia 90:333-339

Feeny P (1976) Plant apparency and chemical defense. Recent Adv Phytochem 10:1-40

Freeman N, Lindgren FT, Ng YS, Nichol AV (1957) Serum lipid analysis by chromatography and infrared spectrophotometry. J biol Chem 277:449 -464

Gerhart DJ, Rittschof D, Mayo SW (1988) Chemical ecology and the search for marine antifoulants. J chem Ecol 14: $1905-1917$

Grigg RW, Polovina JJ, Atkinson MJ (1984) Model of a coral reef ecosystem. III. Resource limitation, community regulation, fisheries yield and resource management. Coral Reefs 3:23-27

Hartman WD (1981) Form and distribution of silica in sponges. In: Simpson TL, Volcani BE (eds) Silicon and siliceous structures in biological systems. Springer-Verlag, New York, p 451-493

Harvell CD, Fenical W (1989) Chemical and structural defenses of Caribbean gorgonians (Pseudopterogorgia spp.): intracolony localization of defense. Limnol Oceanogr 34 : 382-389

Harvell CD, Fenical W, Green CH (1988) Chemical and structural defenses of Caribbean gorgonians (Pseudopterogorgia spp.). I. Development of an in situ feeding assay. Mar Ecol Prog Ser 49:287-294

Hay ME (1984) Patterns of fish and urchin grazing on Caribbean coral reefs: are previous results typical? Ecology $65: 446-454$ 
Hay ME (1991) Fish-seaweed interactions on coral reefs: effects of herbivorous fish and adaptations of their prey. In: Sale PF (ed) The ecology of fishes on coral reefs. Academic Press, San Diego, p 96-119

Hay ME, Kappel QE, Fenical W (1994) Synergisms in plant defenses against herbivores: interactions of chemistry, calcification, and plant quality. Ecology 75:1714-1726

Hay ME, Paul VJ, Lewis SM, Gustafson K, Tucker J, Trindell R (1988) Can tropical seaweeds reduce herbivory by growing at night? Diel patterns of growth, nitrogen content, herbivory, and chemical versus morphological defenses. Oecologia 75:233-245

Humann P (1989) Reef fish identification. New World Publications, Inc, Jacksonville, FL

Huston MA (1985) Patterns of species diversity on coral reefs. A Rev Ecol Syst 16:149-177

Kelly-Borges M, Pomponi S (1992) The simple fool's guide to sponge taxonomy. Harbor Branch Oceanographic Institution, Ft Pierce, FL

Koehl MAR (1982) Mechanical design of spicule-reinforced connective tissue: stiffness. J exp Biol 98:239-267

Lewis JC, VonWallis E (1991) The function of surface sclerites in gorgonians (Coelenterata, Octocorallia). Biol Bull 181; $275-288$

Littler MM, Taylor PR, Littler DS (1983) Algal resistance to herbivory on a Caribbean barrier reef. Coral Reefs 2:111-118

Mattson WJ, Levieux J, Bernard-Dagan C (eds) (1988) Mechanisms of woody plant defenses against insects. SpringerVerlag, New York

McClintock JB (1987) Investigation of the relationship between invertebrate predation and biochemical composition, energy content, spicule armament and toxicity of benthic sponges at McMurdo Sound, Antarctica. Mar Biol $94: 479-487$

Meylan A (1985) The role of sponge collagens in the diet of the hawksbill turtle (Eretmochelys imbricata). In: Bairati A, Garrone R (eds) Biology of invertebrate and lower vertebrate collagens. Plenum Press, New York, p 191-196

Meylan A (1988) Spongivory in hawksbill turtles: a diet of glass. Science 239:393-395

Meylan A (1991) Nutritional characteristics of sponges in the diet of the hawksbill turtle, Eretmochelys imbricata. In: Rützler K (ed) New perspectives in sponge biology. Smithsonian Inst Press, Washington, DC, p 472-477

Paine RT (1964) Ash and calorie determinations of sponge and opisthobranch tissues. Ecology 45:384-387

Paul VJ (1992) Seaweed chemical defenses on coral reefs. In: Paul V (ed) Ecological roles of marine natural products.

This article was submitted to the editor
Comstock Publishing, Ithaca, NY, p $124-150$

Paul VJ, VanAlstyne KL (1988) Chemical defense and chemical variation in the genus Halimeda. Coral Reefs 6: 263-269

Pawlik JR, Chanas B, Toonen RJ, Fenical W (1995) Defenses of Caribbean sponges against predatory reef fish. I. Chemical deterrency. Mar Ecol Prog Ser 127:183-194

Pawlik JR, Fenical W (1992) Chemical defense of Pterogorgia anceps, a Caribbean gorgonian coral. Mar Ecol Prog Ser $87: 183-188$

Pennings SC, Pablo SR, Paul VJ, Duffy JE (1994) Effects of sponge secondary metabolites in different diets on feeding by three groups of consumers. J exp mar Biol Ecol 180:137-149

Randall JE (1983) Caribbean reef fishes, 2nd edn, revised. TFH Publications, Neptune City, NJ

Randall JE, Hartman WD (1968) Sponge feeding fishes of the West-Indies. Mar Biol 1:216-225

Rosenthal GA, Janzen DH (eds) (1979) Herbivores. Their interaction with secondary plant metabolites. Academic Press, New York

VanAlstyne KL, Paul VJ (1992) Chemical and structural defenses in the sea fan Gorgonia ventalina: effects against generalist and specialist predators. Coral Reefs 11: 155-159

VanAlstyne KL, Wylie CR, Paul VJ (1994) Antipredator defenses in tropical Pacific soft corals (Coelenterata: Alcyonacea) Il. The relative importance of chemical and structural defenses in three species of Sinularia. J exp mar Biol Ecol 178:17-34

VanAlstyne KL, Wylie CR, Paul VJ, Meyer K (1992) Antipredator defenses in tropical Pacific soft corals (Coelenterata: Alcyonacea) I. Sclerites as defenses against generalist carnivorous fishes. Biol Bull 182:231-240

Wiedenmayer F (1977) Shallow-water sponges of the western Bahamas. Experentia Suppl 28. Birkhauser Verlag, Stuttgart

Wulff J (1991) Asexual fragmentation, genotype success, and population dynamics of erect branching sponges. $J$ exp mar Biol Ecol 149:227-247

Wylie CR, Paul VJ (1989) Chemical defenses in three species of Sinularia (Coelenterata, Alcyonacea): effects against generalist predators and the butterflyfish Chaetodon unimaculatus Bloch. J exp mar Biol Ecol 129:141-160

Zar JH (1984) Biostatistical analysis, 2nd edn. Prentice-Hall, Englewood Cliffs

Zea S (1987) Esponjas del Caribe Colombiano. Editorial Catalogo Cientifico, Santa Marta, Colombia

Manuscript first received: February 10, 1995

Revised version accepted: May 22, 1995 